"Future entrepreneurs: does the field of study matter? A comparison of students in a South African urban environment"

\begin{tabular}{|c|c|c|}
\hline AUTHORS & \multicolumn{2}{|l|}{$\begin{array}{l}\text { Jean-Marie Mbuya } \\
\text { Chris Schachtebeck }\end{array}$} \\
\hline ARTICLE INFO & \multicolumn{2}{|c|}{$\begin{array}{l}\text { Jean-Marie Mbuya and Chris Schachtebeck (2016). Future entrepreneurs: does } \\
\text { the field of study matter? A comparison of students in a South African urban } \\
\text { environment. Problems and Perspectives in Management, 14(2-1), 228-235. } \\
\text { doi:10.21511/ppm.14(2-1).2016.12 }\end{array}$} \\
\hline DOI & \multicolumn{2}{|c|}{ http://dx.doi.org/10.21511/ppm.14(2-1).2016.12 } \\
\hline RELEASED ON & \multicolumn{2}{|l|}{ Monday, 06 June 2016} \\
\hline JOURNAL & \multicolumn{2}{|c|}{ "Problems and Perspectives in Management" } \\
\hline FOUNDER & \multicolumn{2}{|c|}{ LLC "Consulting Publishing Company "Business Perspectives" } \\
\hline & & $\begin{array}{l}\text { ニE- } \\
\text { =Ẽ }\end{array}$ \\
\hline NUMBER OF REFERENCES & NUMBER OF FIGURES & NUMBER OF TABLES \\
\hline
\end{tabular}

(C) The author(s) 2023. This publication is an open access article. 
Jean-Marie Mbuya (South Africa), Chris Schachtebeck (South Africa)

\title{
Future entrepreneurs: does the field of study matter? A comparison of students in a South African urban environment
}

\begin{abstract}
South Africa is experiencing high rates of unemployment and poverty, particularly among the youth. Entrepreneurship, and the education of it, is often seen as a solution to this socio-economic issue, yet studies show conflicting results on the impact the field of study has on entrepreneurial intent. Accordingly, the aim of this paper is to evaluate and compare the entrepreneurial intention among urban students enrolled for an entrepreneurship qualification versus students who were registered for a non-entrepreneurship related qualification. The article presents quantitative, empirical data collected from 603 students by means of a questionnaire to determine if the field of study has an influence on entrepreneurial intent. The study makes use of descriptive statistics, factor analysis, Kaiser-Meyer-Olkin and Bartlett test in order to discover similarities and differences in entrepreneurial intent in students pursuing entrepreneurial and non-entrepreneurial qualifications. The results reveal that students view entrepreneurship as a valuable career path, regardless of field of study. Both groups hold similar strong positive views and beliefs regarding their intention to pursue this career path. Entrepreneurship students, however, display a marginally higher self-observed personal attitude toward becoming entrepreneurs. Results also show that family support is an important influencer in entrepreneurial intent among students.
\end{abstract}

Keywords: entrepreneurial intention, urban university, entrepreneurship education, urban studies.

JEL Classification: J23, L26, M13.

\section{Introduction}

Entrepreneurship and small business development play a crucial role in today's world economies, which are characterized by high rates of unemployment. Worldwide, governments are working toward developing policies and strategies in order to ensure a favorable environment to support small business development (Malebana \& Swanepoel, 2015). Cassidy (2015) explains that the establishment of the Small Business Development Ministry came as a response to an economic need to support budding entrepreneurs and start-ups in the South African context. An entrepreneurial venture starts with the 'intention', which can be described as the factors that stimulate individuals' desire to become entrepreneurs (Fatoki, 2010).

Statistics South Africa (2014) estimates that there are currently close to 14.5 million unemployed and not economically active youth in South Africa. Furthermore, only $36 \%$ of the youth are considered as unemployed and seeking employment. This figure has been in an upward trend over the past 10 years. Youth play a major role in the long-term growth and development of a nation, and governments should, therefore, ensure that special attention is given to their development. According to Chinguta, Schnurr, Wilson and Torres (2005), there are various benefits associated with the promotion of youth entrepreneurship, some of which include the following:

(C) Jean-Marie Mbuya, Chris Schachtebeck, 2016.

Jean-Marie Mbuya, M.Com., Assistant Lecturer, Department of Business Management, University of Johannesburg, South Africa.

Chris Schachtebeck, M.Com., Lecturer, Department of Business Management, University of Johannesburg, South Africa.
- it brings back previous disadvantaged youth into the mainstream of the economy;

- it fosters local community development due to the fact that youth businesses supply goods and services to the communities;

- it also stimulates creativity innovation and resilience due to the fact that youth are forced to explore new ways of generating an income for their survival.

According to Herrington, Kew and Kew (2014), as stated in the Global Entrepreneurship Monitor (GEM) report, entrepreneurial activity in South Africa remains very low and with a slight decrease (from $10.6 \%$ to $7 \%$ ) from previous years. The GEM report highlighted the fact that an increase in women entrepreneurship had been achieved over the past year due to government support, but the general perception remained that opportunities and confidence to start an entrepreneurial venture were still very low as compared to other countries in SubSaharan Africa. In addition, the GEM report also indicated that the South African entrepreneurial index marginally improved from 2013 to 2014, but was still worryingly low when compared to other developing economies. Further, Herrington, Kew and Kew (2014) indicated that there were few government programs to improve the current state of entrepreneurship within the country, although there were programs run by private companies, such as the Anglo American Zimele program and the South African KikStart initiatives.

The National Youth Development Agency Annual Report (2014) estimated the South African population currently being 50 million, $41.2 \%$ of which were youth. The report emphasized the fact 
that the number of youth involved in entrepreneurial activities could be regarded as significantly low at about $6 \%$ of the total youth population in the country. The findings of the National Youth Development Agency Annual Report (2014) have been introduced in response to the low levels of employment and entrepreneurship among the youth population, with the aim to improve information availability, resource accessibility and mentorship opportunities for the youth.

Economic growth in Southern Africa has been low when compared to other developing nations. Apart from other socio-economic challenges, South Africa, especially, has much lower rates of entrepreneurship than other developing and developed nations. In addition, South Africa suffers from slow economic growth, high rates of unemployment and a slow rate of social transformation (Timm, 2013). South Africa, therefore, needs to support potential and current entrepreneurs in order to address these issues. The establishment of entrepreneurial ventures and SMEs is associated with economic and GDP growth (Nieman \& Nieuwenhuizen, 2014). The National Development Plan (NDP) aims to create 11 million jobs by 2030, which can only be achieved if South Africa meets an annual economic growth rate of $20 \%$ and creates 49000 small- and medium-sized enterprises (Mungadze, 2015). The achievement of the required growth rate can be described as unrealistic when compared to other emerging market growth rates. The focus on SMEs to achieve NDP targets further highlights the important role SMEs play in creating employment opportunities and accelerating economic growth.

Small business and entrepreneurial ventures perform important functions in an economy, most prominently the creation of employment opportunities, increased levels of innovation and pleasant working environments for employees (Mahadea \& Youngleson, 2013). The importance of SMEs for the South African economy as a whole can, thus, not be underestimated, particularly due to the social and economic challenges South Africa faces.

The establishment of the Department of Small Business Development is a sign that government is focusing on the development of entrepreneurship and small business (Mcilhone, 2015). Apart from the government, universities play a critical role in instilling entrepreneurial skills in students. In order to determine the potential future growth rates of entrepreneurship, it is important to evaluate whether students have the intention to become entrepreneurs.
There exists an assumption that students who enroll for entrepreneurship-related programs necessarily have a strong intention to become entrepreneurs; however, a number of studies in the South African context have shown conflicting results (Malabena \& Swanepoel, 2014, 2015; Fatoki, 2013; Fatoki, 2014; Muofhe \& Du Toit, 2011; Gird \& Bagraim, 2008). This study focused on comparing the entrepreneurial intention of students who enroll for entrepreneurship-related qualifications to those who do not have entrepreneurship as a module in their university study curriculum.

\section{Literature review}

The following sections discuss current and prominent literature on the topics of entrepreneurial intention and education, the relationship between the field of study and entrepreneurial intention and urban universities.

1.1. Entrepreneurial intention. Kibler (2013) explains that the intention of starting a business venture is the immediate antecedent of the behavior. This means that the greater the intention to engage in a specific behavior, the higher the likelihood of the behavior occurring. An entrepreneurial intention, therefore, generally refers to an individual's desire to pursue an entrepreneurial activity (Kibler, 2013). Ajzen (2005) explains that entrepreneurial intention has three main influencers, namely attitudes, subjective norms and perceived behavioral control. Firstly, attitudes refer to the understanding individuals have about a particular concept. Secondly, subjective norms relate to the influence an individual's immediate social environment has on decisionmaking. Additional support from friends and family is credited with increased entrepreneurial intent. Thirdly, perceived behavioral control is related to self-efficacy, i.e., the belief an individual holds in himself with regard to chances of succeeding.

1.2. Entrepreneurial education. Entrepreneurship education aims to develop and equip individuals with the necessary skills that will enable them to successfully manage their organization on a daily basis. In addition, individuals are trained to overcome various challenges that may occur in the business environment (Chimucheka, 2014, p. 404). Much of the literature emphasizes the fact that entrepreneurial education plays a crucial role in the development of entrepreneurial intention of individuals. According to Chimucheka (2014), entrepreneurship education has become one of the most important elements in any university curriculum. Entrepreneurship education refers to the process in which an educator enhances a learner's entrepreneurial qualities and skills in order to create and sustain an organization in the world of business. 
Further, Isaacs, Visser and Friedrich (2007) indicated that entrepreneurship education and training was classified into three main categories, namely:

- Entrepreneurship course, which is preliminary designed to cover the stages from economic development to business plan design and with particular attention given to the entrepreneur.

- The entrepreneurial activity, focusing on entrepreneurship and also on the development of viable business plans.

- Entrepreneurial skills, which focuses on enhancing the entrepreneur's skills required in order to perform their duties to the best of their abilities.

Nafukho and Muyia (2010) explain that training and education are important components in developing SME capabilities, in particular, for the purpose of remaining competitive in the marketplace. Therefore, university plays a crucial role in nurturing and developing the skills that students require in order to be able to successfully fulfill their role in the working environment (Jakopec, Miljkovic \& Susanj, 2013, p. 289). It is through a student's learning process that students assess their capacity of pursuing entrepreneurial activities in their future career paths (Pihie, Bagheri \& Sani, 2013).

Soleimanpour, Tohidlu and Bakhtiari (2012) indicated that education resources appeared to be the biggest challenge for the development of an entrepreneurial spirit among the students. Therefore, a lack of sufficient funding will negatively impact on a university's ability to foster an entrepreneurial spirit.

\subsection{The relationship between field of study and} entrepreneurial intention. A number of studies have investigated the relationship between field of study and entrepreneurial intention in a university environment. Grassl and Jones (2005) indicate that distinct nuances exist between students of differing fields of study when considering entrepreneurial intent. The studies have produced conflicting results which call for further investigation.

A number of authors conclude that a definite relationship exists between entrepreneurial education and entrepreneurial intent (Fatoki, 2014; Ramkhumise, 2014; Muofhe \& Du Toit, 2011; Malabena \& Swanepoel, 2014, 2015; Susanj, Jakopec \& Krecar, 2015). Furthermore, Otuya, Kibas, Gichira \& Martin (2013) investigated the impact of entrepreneurial education in influencing student's entrepreneurial intentions. The study reported that students who partook in an entrepreneurial program exhibited greater intention towards entrepreneurship than those students who were not exposed to entrepreneurship education. These findings also concur with those reported by Gerba (2012), who concludes that students who are registered for business-related qualifications tend to have a higher attraction towards entrepreneurship than those registered for engineeringrelated qualifications. In addition, Ho, Low and Wong (2014) also emphasized that an entrepreneurial education gives students a better understanding of the venture creation process and the necessary skills required for venture creation, thereby confirming a positive relationship between entrepreneurship education and intention. Also, business students seem to have thought about entrepreneurship much more than other students; however, they are less excited about entrepreneurship. A possible reason for this finding could be that business studies are much more aware of the realities and high failure rate of entrepreneurial ventures (Grassl and Jones, 2005).

In contrast, a number of other authors conclude that entrepreneurial intent is more strongly influenced by a comprehensive study offering which is not necessarily focused on entrepreneurship education (Wu \& Wu, 2008; Solesvik, Westhead \& Matlay, 2014; Abbas, 2013).

1.4. Urban universities. Rodin (2005) broadly defines the urban university as being located in an inner-city neighborhood. Shafran (2015) describes the role of an urban university as addressing urban issues, which typically are centered on the needs of urban dwellers. The author goes further to say that due to the rapidly changing nature of the urban environment, created by a constantly shifting demographic, the urban university/academy has to constantly adapt proactively by changing its offering to address urban challenges. Rodin (2005) goes further to say that due to the location of an urban university, the main factors driving its curriculum development are those faced in its immediate urban environment. This means that an urban university has to be aware of the urban sprawl and associated challenges, as well as traditional inner-city problems. North (2002) further highlighted that entrepreneurship education could not be standardized due to the fact that educators in urban areas, townships and rural areas did not hold the same professional and education levels. Therefore, it remains a challenge offering equally structured and delivered entrepreneurship programs in both urban and rural areas. The implication is, thus, that a gamechanging curriculum for an urban South African university should include elements of poverty alleviation and addressing the issue of joblessness.

\section{Research methodology}

The approach utilized in this research was an exploratory research design using quantitative research. 
The target population of the study included all undergraduate students enrolled in programs delivered by the Faculty of Management, at the University of Johannesburg. The sample size was 603 students. Participation in the survey was voluntary and students who participated were informed of their anonymity and that their participation was not subject to any benefit. Prior to the completion of the survey, a brief explanation of the study was provided to the students in order to improve their understanding of the questionnaire, its purpose and also to clarify why some sections were included.

The survey questionnaire used to collect the data was adapted from an instrument developed by Linan and Chen (2006), due to the fact that the original study was not conducted in a South African context. The survey questionnaire was divided into two sections, namely Section A of the instrument comprising questions related to the demographics, which included the age of the participant, the province of origin, the mother tongue, field of study, study qualifications and a question relating to their intention of starting a business in future. Section B used a 7-point Likert scale in order to accurately gauge responses. This section comprised questions related to entrepreneurial intention and was structured as follows: personal attitude, professional options, subjective norms, entrepreneurial capacity and entrepreneurial intention.

Data were analyzed using SPSS (Statistical Package of Social Sciences) version 22. The reliability of the sample was tested using the Cronbach Alpha coefficient and the sample adequacy was tested using the Kaiser-Meyer-Olkin and Bartlett's test. In addition, other tests were also performed, such as $t$-test, ANOVA and frequency analysis.

Ethical clearance for the study was obtained from the Faculty of Management.

\section{Findings}

3.1. Section A - demographics. The sample of the study was made up of $56 \%$ females and $44 \%$ males. The majority of the respondents $(47.6 \%)$ originated from Gauteng. Most of the respondents (92\%) indicated that they did not own a business and $(89.3 \%)$ were undergraduate students (first- to thirdyear students). Students with entrepreneurship as a major represented $21 \%$ of the sample and nonentrepreneurship students, which included students with majors in business management, engineering, human ressources and accounting, represented 79\% of the sample. Although commerce students studying business management, human resources and accounting may have entrepreneurship as a minor in their curriculum, for the purpose of the study, the comparison was strictly done among students who were studying toward an entrepreneurship qualification versus the students who pursued other qualifications.

3.2. Section $\mathbf{B}$ - entrepreneurial intention. This section discusses the findings of the study. The tables are structured according to the main antecedents of entrepreneurial intent, namely Personal Attitude (PA), Subjective Norm (SN), Entrepreneurial Capacity (EC) and overall selfperceived EI (Entrepreneurial Intent).

Table 1 indicates the means of the two groups (entrepreneurship vs non-entrepreneurship students) for the four main antecedents of entrepreneurial intent.

Table 1. Mean of entrepreneurship versus nonentrepreneurship for various factors

\begin{tabular}{|c|l|c|c|c|}
\hline & \multicolumn{1}{|c|}{ Student type } & Frequency & Mean & Std. deviation \\
\hline \multirow{2}{*}{ PA } & Entrepreneurship & 86 & 5.9209 & 1.05842 \\
\cline { 2 - 5 } & Non-entrepreneurship & 517 & 5.6316 & 1.23007 \\
\hline \multirow{2}{*}{ SN } & Entrepreneurship & 86 & 5.8018 & 1.05659 \\
\cline { 2 - 5 } & Non-entrepreneurship & 517 & 5.7037 & 1.12828 \\
\hline \multirow{2}{*}{ EC } & Entrepreneurship & 86 & 5.0814 & 0.94014 \\
\cline { 2 - 5 } & Non-entrepreneurship & 517 & 4.5220 & 1.26806 \\
\hline \multirow{2}{*}{ EI } & Entrepreneurship & 86 & 5.2294 & 1.05228 \\
\cline { 2 - 5 } & Non-entrepreneurship & 517 & 4.7522 & 1.25721 \\
\hline
\end{tabular}

The overall mean indicated that all selected scales, namely personal attitude and subjective norm, had overwhelmingly positive means, except for entrepreneurial capacity and entrepreneurial intention, which had moderate to high means. This shows that both entrepreneurship and non-entrepreneurship students have a strong inclination regarding their personal attitude (Mean: 5.9 (entrepreneurship) versus 5.6 (non-entrepreneurship) and subjective norm attitude (Mean: 5.8 (entrepreneurship) versus 5.7 (nonentrepreneurship), on the one hand. On the other hand, entrepreneurship students tend to have a stronger inclination (Mean: 5) to entrepreneurial self-efficacy than non-entrepreneurship students (Mean: 4.5). Entrepreneurship students also tend to have a stronger inclination to entrepreneurship intention (Mean: 5.2), than non-entrepreneurship students (Mean: 4.7).

3.3. Analysis of reliability and sample adequacy. This section outlines the results of the reliability analysis, as well as sample adequacy. Table 2 shows the results of the reliability analysis, namely Cronbach Alpha.

Table 2. Cronbach Alpha

\begin{tabular}{|l|c|}
\hline \multicolumn{1}{|c|}{ Factor } & Cronbach Alpha \\
\hline Personal Attitude & 0.849 \\
\hline Subjective Norm & 0.633 \\
\hline Entrepreneurial Capacity & 0.867 \\
\hline Entrepreneurial Intention & 0.903 \\
\hline
\end{tabular}


The Cronbach Alpha is a statistical test performed to measure the scale's internal consistency. It is suggested that the coefficient should be $>0.7$ (Pallant, 2010, p. 97). The analysis shows all scales were higher than 0.70 expect for subjective norm. Therefore, it can be argued that these scales demonstrated a high level of internal consistency. The reason for the results of subjective norm can be attributed to the small number of constructs contained for the variable.

Two tests were performed to test factorability of data, namely Bartlett's test of sphericity and KaiserMeyer-Olkin to measure adequacy of the sample. It is suggested that the minimum value is set at 0.6 for $\mathrm{KMO}$ and that Bartlett's test should be significant at $p<0.05$ (Pallant, 201, p. 192). The five items of the professional attraction, three items of the subjective norm, and six items of the entrepreneurial capacity measures were subjected to principal axis factoring (PAF) to establish if the expected factor structure holds for the South African context. The presence of many correlation coefficients above 0.3 , a KaiserMeyer-Olkin value of 0.873 , and a statistically significant Barlett's Test of Sphericity demonstrated the data was suitable for factor analysis.

Principal components analysis revealed three factors with eigenvalues exceeding 1, explaining a total of 52.4 percent of the variance. Inspection of the screeplot confirmed it would be appropriate to retain three components. Oblimin rotation was performed revealing three components which were consistent with professional attraction, entrepreneurial capacity and subjective norm factors from the instrument of Linan and Chen (2006) (Table 3). This was necessary as the instrument was adapted for language for the South African context.

Table 3. Pattern matrix

\begin{tabular}{|c|c|c|c|c|}
\hline \multirow{2}{*}{\multicolumn{2}{|c|}{ Statement }} & \multicolumn{3}{|c|}{ Factor } \\
\hline & & \multirow{2}{*}{$\begin{array}{c}1 \\
.878\end{array}$} & \multirow{2}{*}{$\begin{array}{c}2 \\
.030\end{array}$} & \multirow{2}{*}{$\begin{array}{c}3 \\
.014 \\
\end{array}$} \\
\hline \multirow{5}{*}{ PA } & Being an entrepreneur would entail great satisfactions for me & & & \\
\hline & A career as entrepreneur is attractive for me & .829 & -.002 & -.042 \\
\hline & Among various options, I would rather be an entrepreneur & .807 & -.024 & -.060 \\
\hline & If I had the opportunity and resources, l'd like to start a firm & .653 & -.028 & .150 \\
\hline & Being an entrepreneur implies more advantages than disadvantages to me & .382 & -.137 & .036 \\
\hline \multirow{6}{*}{ EC } & I know how to develop an entrepreneurial project & -.067 & -.808 & -.043 \\
\hline & I know the necessary practical details to start a firm & -.117 & -.763 & .016 \\
\hline & I can control the creation process of a new firm & .097 & -.739 & .029 \\
\hline & If I tried to start a firm, I would have a high probability of succeeding & .098 & -.670 & -.029 \\
\hline & I am prepared to start a viable firm & .271 & -.581 & .036 \\
\hline & To start a firm and keep it working would be easy for me & .092 & -.531 & .062 \\
\hline \multirow{3}{*}{ SN } & Your friends & -.041 & .082 & .925 \\
\hline & Your close family & .140 & .051 & .476 \\
\hline & Your collegues' & -.064 & -.118 & .471 \\
\hline
\end{tabular}

Similarly, the six items of the entrepreneurial intention were subjected to principal axis factoring (PAF) to test for a single factor in the South African context. The presence of many correlation coefficients above 0.3 , a Kaiser-Meyer-Olkin value of 0.914, and a statistically significant Barlett's Test of Sphericity demonstrated the data were suitable for factor analysis. Principal axis factoring produced a single factor explaining 74.2 percent of the variation.

Table 4 outlines the results of the $t$-test, which is the difference in the means of two groups, namely entrepreneurship and non-entrepreneurship students.

Table 4. Difference in means of factors of entrepreneurial and non-entrepreneurial groups

\begin{tabular}{|c|c|c|c|c|c|c|c|}
\hline \multirow[t]{2}{*}{ Factors } & \multirow[t]{2}{*}{$t$} & \multirow[t]{2}{*}{ Df } & \multirow{2}{*}{$\begin{array}{c}\text { Sig. } \\
\text { (2-tailed) }\end{array}$} & \multirow{2}{*}{ Mean difference } & \multirow{2}{*}{$\begin{array}{l}\text { Std. error } \\
\text { difference }\end{array}$} & \multicolumn{2}{|c|}{$\begin{array}{l}\text { 95\% confidence interval of the } \\
\text { difference }\end{array}$} \\
\hline & & & & & & Lower & Upper \\
\hline PA & -2.022 & 111.433 & 0.46 & -31800 & .15724 & -.62956 & -.00643 \\
\hline SN & -.348 & 601 & .728 & -.04447 & .12786 & -.29559 & .20664 \\
\hline EC & -1.267 & 601 & .206 & -17961 & .14181 & -.45812 & .09890 \\
\hline $\mathrm{El}$ & -.367 & 601 & .714 & -.05203 & .14188 & -33067 & .22661 \\
\hline
\end{tabular}

The $t$-test was carried out in order to compare the difference between two means in relation to the variation in the data. It is suggested that if the $p$-value is greater than 0.05 , then the variability in the two conditions is about the same; on the other hand, if the $p$-value is less than 0.05 , it means that 
the variability in the two conditions is not the same. Therefore, based on Table 4, it can be seen that all variables, namely SN ( $p$-value $=0.728), \quad \mathrm{EC}$ $(p$-value $=0.206)$ and EI $(p$-value $=0.714)$ are all greater than 0.05 , except for PA $(p$-value $=0.046)$. Therefore, it can be argued that there is no significant difference between the two groups, namely, entrepreneurship and non-entrepreneurship students, except for Personal Attitude where a difference could be found.

\section{Discussion}

This study aimed to compare the entrepreneurial intention of students who were studying toward an entrepreneurship qualification versus the ones who were registered for non-entrepreneurship qualifications, such as human resources, accounting or marketing. Findings from the study suggest that both entrepreneurship and non-entrepreneurship students tend to have similar views and believe that entrepreneurship is their career of choice in future (Personal Attitude). Both groups (entrepreneurship and non-entrepreneurship students) also emphasized the fact that entrepreneurship as a career option would be more beneficial to them on the condition that opportunities and the required resources were available. However, entrepreneurship students showed a stronger inclination to become entrepreneurs, when compared to their non-entrepreneurial counterparts. This finding is supported by findings of Muofhe and Du Toit (2011), which indicated that entrepreneurship students were more attracted to an entrepreneurial career than non-entrepreneurship students. It should be noted, however, that a significant amount of time has elapsed between the studies and, therefore, the associated changing economic, social, political and educational landscape.

The second main measure, subjective norm, which measured to what extent the closer environment positively or negatively impacts on the decisions of both groups to start an entrepreneurial career, revealed that perceived support from close family, friends and colleagues positively impacted on the respondent's intention to become entrepreneurs. This is consistent with the findings of Denanyoh, Adjei and Nyamekye (2015), which suggested that the closer environment (family support) provided an important necessary "emotional" support to an individual who intended to start his own business venture.

The third main measure, entrepreneurial capacity, showed that both groups (entrepreneurship and nonentrepreneurship students) emphasized the fact they had a clear understanding of the process of starting an entrepreneurial venture. The observed mean for the entrepreneurship group, however, was higher than for the non-entrepreneurship, albeit by a small margin. This can be attributed to the entrepreneurial knowledge and training initiatives that entrepreneurship students have been exposed to, when compared to their non-entrepreneurial counterparts. This is consistent with the findings of a study conducted by Beeka and Rimmington (2011) that entrepreneurs in African countries have strong abilities and capabilities to run business ventures.

Regarding entrepreneurial intention, both groups (entrepreneurship and non-entrepreneurship students) indicated that they had high intention of pursuing an entrepreneurial career. Both groups indicated that they were willing to go the "extra mile" in order to start and sustain a business venture in the future. This supports the findings of a study conducted by Neneh (2014) in an African country that students had generally high entrepreneurial intention. Therefore, it is important for tertiary institutions to equip students with the relevant knowledge and skills to become future entrepreneurs and tackle the current challenges of high unemployment that the country and the world in general are facing.

While the findings revealed minor differences with regard to entrepreneurial intent between entrepreneurship and non-entrepreneurship students, entrepreneurship students still displayed higher levels of personal attitude, subjective norm and entrepreneurial capacity.

\section{Conclusion}

The findings of the study revealed that both groups (entrepreneurship and non-entrepreneurship) students had a high desire to pursue an entrepreneurial career after completing their studies. Therefore, universities should play an important role in nurturing the entrepreneurial spirit of their students in order to prepare youth entrepreneurs that will play a transformative role in the South African economic environment. The nature of the urban environment, together with its associated challenges, allows universities to play an important role in uplifting surrounding communities. Furthermore, the diverse demographic of the urban environment gives urban universities the opportunity to meet their transformation agenda, as well as address the inequalities of South Africa's past. The urban sprawl also gives entrepreneurs in the surrounding communities the opportunity to reach a growing market with a diverse set of needs. It should be noted, however, that the onus on developing entrepreneurs should not only fall on urban universities, but governmental support is also critical in growing the number of entrepreneurs, particularly among South Africa's youth. 
When comparing the findings of this study to those in the GEM report (Herrington, Kew \& Kew, 2014), there are indications that there could exist a change in perception toward entrepreneurship as a future career path, with both entrepreneurship and nonentrepreneurship students exhibiting favorable tendencies.

\section{Recommendations for further research}

While a large amount of research has been performed in the area of entrepreneurial intent, many studies only focus on specific geographic areas and universities. A broad multi-province study could indicate differences in entrepreneurial intent between students from a rural and urban background, as well as from differing demographic backgrounds. In addition, there exists scope to determine how the measures of entrepreneurial intent would translate into new venture creation. This information would provide valuable insight into the real-world ability and desire to start new ventures after a student has completed their studies.

An important further research area could include conducting a longitudinal study on how entrepreneurial intent changes as students progress through their qualification. This would provide information on how specific learning initiatives affect entrepreneurial intent.

Further comparative research could be extended into measuring the entrepreneurial intent of students of specific disciplines, such as the fine arts and medicine. These disciplines are rarely exposed to entrepreneurial education, as compared to other areas of specialization, such as managerial students.

\section{Managerial implications}

Entrepreneurship development plays a crucial role in the economy, considering the challenges that the country faces in creating job opportunities. It is, therefore, important that Government and universities work hand in hand in order to stimulate and promote an entrepreneurial culture among the young population registered in tertiary institutions.

It is further of importance that students studying toward a non-entrepreneurship qualification not be excluded from the aim of building future entrepreneurs. These students obtain hard skills during their studies, which can be used as a basis for entrepreneurial action. Opportunities for entrepreneurial development, therefore, need to be targeted at non-entrepreneurship students as well. It is, furthermore, important that entrepreneurial intent of all students be measured in order to more effectively target and develop those who have ambitions to become entrepreneurs.

In addition, in the entrepreneurship course curriculum, entrepreneurship and nonentrepreneurship students should be exposed to practical case studies in order to improve their ability to successfully manage an organization in the business environment. Entrepreneurs operating in different fields should also be associated in the process in order to share their experience and provide guidance to students who intend to pursue an entrepreneurial career.

International exchange programs should also be implemented in order to expose students from different cultures and professional backgrounds in order to improve their learning experience. Social media sites (Twitter, Facebook, and LinkedIn) should also be used in order to communicate more effectively with students regarding major events or information related to entrepreneurship in their different areas of study.

\section{References}

1. Abbas, L.N. (2013). Engineering students: what factors effects their entrepreneurial intention, IOSR Journal of Humanities and Social Sciences, 15 (2), pp. 35-40.

2. Ajzen, I. (2005). Attitudes, personality and behavior, $2^{\text {nd }}$ edition, Berkshire: Open University Press.

3. Beeka, H.B. and Rimmington, M. (2011). Entrepreneurship as a career option for African youths, Journal of Developmental Entrepreneurship, 16 (1), pp. 145-164.

4. Cassidy, S. (2015). Government is business bugbear. Accessed: http://www.iol.co.za/business/news/govt-isbusiness-bugbear-1.1891841\#.VbiGHbOqqko. Date of access: 29 July 2015.

5. Chimucheka, T. (2014). Entrepreneurship education in South Africa, Mediterranean Journal of Social Sciences, 5 (2), pp. 403-415.

6. Chinguta, F., Schnurr, J., Wilson, D.J. and Torres, V. (2005). Being "Real" about entrepreneurship in Eastern and Southern Africa: Implications for adults, institutions and sector structures. SEED working paper 72.

7. Denanyoh, R., Adjei, K. and Nyamekye, G.F. (2015). Factors that impact on entrepreneurial intention of tertiary students in Ghana, International Journal of Business and Social Research, 5 (3), pp. 19-29.

8. Fatoki, O.O. (2010). Graduate entrepreneurial intention in South Africa: motivations and obstacles, International Journal of Business Management, 5 (9), pp. 87-98.

9. Fatoki, O.O. (2013). The Determinants of Immigrant Entrepreneurs' Growth Expectations in South Africa, Mediterranean Journal of Social Sciences, 37 (3), pp. 209-216.

10. Fatoki, O.O. (2014). The entrepreneurial intention of undergraduate students in South Africa: the influences of entrepreneurship education and previous work experience, Mediterranean Journal of Social Sciences, 5 (7), pp. 294-299. 
11. Gerba, D.T. (2012). Impact of entrepreneurship education on entrepreneurial intentions of business and engineering students in Ethiopia, African Journal of Economic and Management studies, 3 (2), pp. 258-277.

12. Gird, A. and Bagraim, J. (2008). The theory of planned behavior as predictor of entrepreneurial intent amongst final-year university students, South African Journal of Psychology, 38 (4), pp. 711-724.

13. Grassl, W. and Jones, J. (2005). Entrepreneurial Intent among Students: Are Business Undergraduates Different? Available at: www.snc.edu. Accessed: 11 July 2015.

14. Herrington, M., Kew, J. and Kew, P. (2014). Global Entrepreneurship Monitor, South African Report. Available at: http://www.gemconsortium.org/docs/3336/gem-south-africa-2014-report. Accessed: 12 July 2015.

15. Ho, Y.P., Low, P.C. and Wong, P.K. (2014). Do university entrepreneurship programs influence students' entrepreneurial behavior? An empirical analysis of university students in Singapore, Advances in the Study of Entrepreneurship, Innovation and Economic Growth, 24 (1), pp. 65-87.

16. Issacs, E., Visser, K. and Friedrich, C. (2007). Entrepreneurship education and training at the further education and training (FET) level in South Africa, South African Journal of Education, 27 (1), pp. 613-629.

17. Jakopec, A., Miljkovic, I. and Susanj, Z. (2013). Predictors of entrepreneurial intentions of students of economics, Studia Psychologica, 55 (4), pp. 289-297.

18. Kibler, E. (2013). Formation of entrepreneurial intention in a regional context, Entrepreneurship \& Regional Development, 25 (3-4), pp. 293-323.

19. Linan, F. and Chen, Y.W. (2006). Testing the Entrepreneurial Intention Model on a Two-Country Sample, Working Paper. Universitat Autonoma de Barcelona.

20. Mahadea, D. and Youngleson, J. (2013). Entrepreneurship \& Small Business Management, $1^{\text {st }}$ edition, Cape Town: Pearson.

21. Malebana, M.J. and Swanepoel, E. (2014). The relationship between exposure to entrepreneurship education and entrepreneurial self-efficacy, Southern African Business Review, 18 (1), pp. 1-26.

22. Malebana, M.J. and Swanepoel, E. (2015). Graduate entrepreneurial intentions in the rural provinces of South Africa, Southern African Business Review, 19 (1), pp. 89-111.

23. Mcilhone, M. (2015). SA: Department reviews small business programs. Available at: http://africanbrains.net/2015/05/20/sa-department-reviews-small-business-programs/. Accessed: 21 May 2015.

24. Mungadze, S. (2015). Job-creation aims of NDP may be unrealistic. Available at: http://www.bdlive.co.za/national/2015/05/05/job-creation-aims-of-ndp-may-be-unrealistic. Accessed: 13 May 2015.

25. Muofhe, N.J. and Du Toit, W. (2011). Entrepreneurial education's and role models' influence on career choice, South African Journal of Human Resource Management, 9 (1), pp. 1-15.

26. Nafukho, F.M. and Muyia, M.A.H. (2010). Entrepreneurship and socioeconomic development in Africa: a reality or myth? Journal of European Industrial Training, 34 (2), pp. 96-109.

27. National Youth Development Agency. (2014). NYDA Annual Report 2014. Available at: http://www.nyda.gov.za/About-Us/strategy/Pages/Annual-Reports.aspx. Accessed: 2 August 2015.

28. Neneh, B.N. (2014). An Assessment of Entrepreneurial Intention among University Students in Cameroon, Mediterranean Journal of Social Sciences, 5 (20), pp. 542-552.

29. Nieman, G. and Nieuwenhuizen, C. (2014). Entrepreneurship: A South African perspective, $3^{\text {rd }}$ edition, Pretoria: Van Schaik Publishers.

30. North, E. (2002). A decade of entrepreneurship education in South Africa, South African Journal of Education, 22 (1), pp. 24-27.

31. Otuya, R., Kibas, P., Gichira, R. and Martin, W. (2013). Entrepreneurship education: influencing students' entrepreneurial intentions, International Journal of Innovative Research \& Studies, 2 (4), pp. 133-148.

32. Pallant, J. (2010). SPSS survival manual, $4^{\text {th }}$ edition, New York: Allen \& Unwin.

33. Pihie, Z.A.L., Bagheri, A. and Sani, Z.H.A. (2013). Knowledge of cognition and entrepreneurial intention: Implications for learning entrepreneurship in public and private universities, Proceedings of the $9^{\text {th }}$ International Conference of Cognitive Science, Malaysia.

34. Rodin, J. (2005). The $21^{\text {st }}$ century urban university, Journal of the American Planning Association, 71 (3), pp. $237-249$.

35. Shafran, A. (2015). The future of the urban academy, City: analysis of urban trends, culture, theory, policy \& action, 19 (2-3), pp. 303-305.

36. Soleimanpour, M.R, Tohidlu, S. \& Bakhtiari, R. (2012). Identification educational barriers to the development of entrepreneurial spirit in Zanjan University Students, Journal of American Science, 8 (8), pp. 507-511.

37. Solesvik, M., Westhead, P. and Matlay, H. (2014). Cultural factors and entrepreneurial intention, Education + Training, 56 (8/9), pp. 680-696.

38. Statistics South Africa. (2014). National and provincial labor market: Youth. Available at: http://beta2.statssa.gov.za/publications/P02114.2/P02114.22014.pdf. Accessed: 4 August 2015.

39. Susanj, Z., Jakopec, A. and Krecar, I.M. (2015). Verifying the model of predicting entrepreneurial intention among students of business and non-business orientation, Management, 20 (2), pp. 49-69.

40. Timm, S. (2013). Global entrepreneurship report puts SA below average. Available at: http://mg.co.za/article/2013-04-26-00-report-puts-sa-below-average. Accessed: 3 March 2015.

41. Wu, S. and Wu, L. (2008). The impact of higher education on entrepreneurial intentions of university students in China, Journal of Small Business and Enterprise Development, 15 (4), pp. 752-774. 